\title{
PENGARUH KONSELING KELOMPOK BEHAVIOR TEKNIK KONTRAK PERILAKU DALAM MENURUNKAN KETERGANTUNGAN MEROKOK DI KELAS XI PERHOTELAN 2 SMK NEGERI 2 BAGOR NGANJUK
}

\author{
Eva Yuanita Ferdian \\ SMK Negeri 2 Bagor \\ agvaaflah09@gmail.com \\ Dwi Ridhowati \\ SMP Negeri 2 Merakurak-Tuban \\ dwiridhowati@gmail.com
}

\begin{abstract}
Abstrak
Semua orang tahu bahwa merokok adalah kebiasaan buruk bagi kesehatan. Namun masih banyak orang yang masih terus melakukan kebiasaan buruk ini. Bimbingan dan konseling memiliki peranan yang penting dalam menangani permasalah siswa. Tujuan penelitian bimbingan konseling adalah untuk mengetahui pengaruh konseling kelompok dengan teknik kontrak perilaku untuk menurunkan kebiasaan merokok. Peneliti mengambil penilitian di kelas XI Perhotelan 2 SMK Negeri 2 Bagor. Berdasarkan need asesmen yang dilakukan oleh peneiti di awal bulan juli dengan menggunakan aplikasi google formulir. Kelas XI Perhotelan 2 yang berjumlah 34 siswa terdiri dari 5 siswa dan 29 siswi, diketahui hasil need asesmen bahwa kelima siswa tersebut merasa sulit untuk mengurangi kebiasaan merokok. Proses penelitian ini berlangsung dua siklus yaitu siklus 1 dan siklus. Teknik pengumpulan data dengan pengamatan dan kuesioner. Hasil dari siklus 1 yaitu 7,2 dan siklus 2 yaitu 5. Konseling kelompok behavior tehnik kontrak perilaku dapat berpengaruh dalam menurunkan ketergantungan merokok di kelas XI Perhotelan 2 SMK Negeri 2 Bagor Nganjuk.
\end{abstract}

Kata Kunci: kontrak perilaku, ketergantungan merokok, konseling

\begin{abstract}
Everyone knows that smoking is a bad habit for health. However, there are still many people who continue to do this bad habit. Guidance and counseling have an important role in dealing with student problems. The research objective of counseling guidance is to determine the effect of group counseling with behavior contract techniques to reduce smoking habits. Researchers took research in class XI Hospitality 2 SMK Negeri 2 Bagor. Based on the need for an assessment conducted by the researcher at the beginning of July using the Google Forms application. Class XI Hospitality 2, amounting to 34 students consisting of 5 students and 29 students, it is known that the results of the need assessment showed that the five students found it difficult to reduce smoking. The research process took place in two cycles, namely cycle 1 and cycle. Data collection techniques with observations and questionnaires. The results of cycle 1 are 7,2 and cycle 2 are 5. Behavior group counseling of behavior contract techniques can have an effect in reducing smoking dependence in class XI Hospitality 2 at SMK Negeri 2 Bagor Nganjuk.
\end{abstract}

Keywords: behavioral contracts, smoking addiction, counseling 


\section{LATAR BELAKANG}

Semua orang tahu bahwa merokok adalah kebiasaan buruk bagi kesehatan. Namun masih banyak orang yang masih terus melakukan kebiasaan buruk ini. Pasalnya ada banyak bahaya merokok lainnya yang tidak disadari seorang perokok, misalnya penurunan daya tahan tubuh sehingga mereka lebih rentan terhadap penyakit infeksi. Hal tersebut cenderung terjadi secara singkat dan mungkin menyebabkan dampak kesehatan pada kehidupan sehari-hari seorang perokok. Bahkan bahaya merokok bagi kesehatan ini tidak hanya berlaku bagi perokok saja, tetapi juga orang-orang yang ada di sekitar perokok pun berisiko tinggi terkena efek rokok tersebut, meskipun mereka sendiri tidak merokok.

Bimbingan dan konseling memiliki peranan yang penting dalam menangani permasalah siswa. Peneliti mengambil penilitian di kelas XI Perhotelan 2 SMK Negeri 2 Bagor. Berdasarkan need asesmen yang dilakukan oleh Guru BK di awal bulan juli tahun 2018 dengan menggunakan aplikasi google formulir. Kelas XI Perhotelan 2 yang berjumlah 34 siswa terdiri dari 5 siswa dan 29 siswi, diketahui hasil need asesmen bahwa kelima siswa tersebut merasa sulit untuk mengurangi kebiasaan merokok. Berdasarkan hasil observasi guru BK dan wawancara yang dilakukan pada awal bulan juli tahun 2018 kepada wali kelas dan petugas tata tertib dimana di kelas XI Perhotelan 2 SMK Negeri 2 Bagor Nganjuk, siswa laki-lakinya mempunyai kebiasaan merokok meskipun tata tertib sekolah tidak memperbolehkan merokok di sekolah. Ketika ketahuan siswa langsung membuang, ada yang lari meski beberapa kali sudah mendapat sanksi, tetapi belum ada perubahan. Dimana konseli pertama kali mengenal dan mencoba rokok dari pergaulan dan lingkungannya, pertama kali mencoba rokok ketika bertemu dan berkumpul dengan temannya ada keinginan untuk mencoba ditambah lagi teman-temannya juga mendukung dan mencoba bersama. Lambat laun ada rasa tidak nyaman kalau tidak merokok dan semakin hari semakin bertambah jumlahnya. Bahkan ketika keinginan merokok itu datang tidak bisa menahan sehingga di lingkungan sekolah akhirnya merokok meski masih ada rasa takut karena peraturan sekolah tidak membolehkan siswa merokok. Hukuman dari tata tertib tidak membuat jera dan mengulanginya lagi.

Dari masalah tersebut menurunkan ketergantungan merokok siswa, metode dalam penanganan tersebut dapat menggunakan konseling kelompok behavioristik teknik kontrak perilaku, dengan konseling kelompok pendekatan behavioral menggunakan teknik kontrak perilaku diharapkan dapat menurunkan ketergantungan merokok. Dimana konseli diajak untuk membuat komitmen dengan membuat kontrak pada konseling kelompok dengan teknik behavior contract (kontrak perilaku), karena teknik ini merupakan teknik yang dapat merubah perilaku seseorang untuk menurunkan ketergantungan pada hal buruk.

Berdasarkan observasi guru BK dan latar belakang masalah tersebut maka perlu diteliti lebih lanjut apakah konseling kelompok behavior teknik kontrak perilaku dapat berpengaruh dalam menurunkan ketergantungan merokok di kelas XI Perhotelan 2 SMK Negeri 2 Bagor Nganjuk.

\section{METODOLOGI}

Sampel yang diambil dalam penelitian tindakan kelas ini adalah kelas XI Perhotelan 2 SMK Negeri 2 Bagor Nganjuk, siswa lakilakinya mempunyai ketergantungan merokok meskipun tata tertib sekolah tidak memperbolehkan merokok di sekolah.

Penelitian tindakan kelas ini di sebut dengan PTKBK dengan menggunakan 3 siklus, yang terdiri dari 4 tahap kegiatan, yaitu perencanaan, tindakan, pengamatan, dan refleksi.

Pada tahap perencanaan kegiatan yang dilakukan adalah sebagai berikut; (1) Jadwal kegiatan layanan konseling kelompok, (2) RPLBK layanan konseling kelompok yang terdiri dari 3 kali pertemuan setiap pertemuan 45 menit.

Analisis data yang digunakan dalam penelitian tindakan kelas ini adalah data pelayanan implementasi konseling kelompok behavior contract untuk menurunkan ketergantungan merokok. Sumber data yang digunakan dalam penelitian ini adalah 5 siswa yang mengalami masalah ketergantungan merokok. Teknik pengumpulan data yang digunakan dalam penelitian ini adalah pengamatan dan kuesioner. Pengamatan dilakukan saat layanan konseling kelompok, dengan Indikator yang diamati antara lain keaktifan siswa, keberanian siswa dalam memberikan respon, keberanian siswa dalam mengambil keputusan, komitmen siswa untuk bisa berubah menjadi lebih baik. Sedangkan kuesioner diberikan sebelum layanan konseling kelompok dan setelah layanan konseling kelompok. Instrumen penelitian yang digunakan untuk mengukur tingkat ketergantungan merokok adalah menggunakan kuesioner Fagerstrom (Becoña et al., 2010). Dalam angket ini terdiri dari 6 pernyataan. Pernyataan itu antara lain: 1) Setelah bangun tidur berapa lama waktu yang Anda butuhkan untuk mulai mengonsumsi rokok?, 2) Apakah 
Anda mengalami kesulitan menahan diri untuk merokok ditempat yang tidak diizinkan? Misal di sekolah, masjid, perpustakaan, super market dll , 3) Waktu rokok pada saat kapan yang paling sulit dihentikan, 4) Berapa banyak Anda merokok dalam sehari?, 5) Apakah Anda merasa lemas ketika anda tidak merokok?, 6) Apakah Anda tetap merokok walaupun Anda sedang sakit?.

Indikator keberhasilan dalam penelitian ini yaitu dengan membandingkan hasil skor pengisian sebelum tindakan konseling kelompok behavior teknik kontrak perilaku dan setelah tindakan yang diperoleh subjek. Dengan demikian dapat diketahui berhasilnya pengaruh konseling kelompok behavior teknik kontrak perilaku untuk menurunkan ketergantungan merokok pada siswa kelas XI Perhotelan 2 SMK Negri 2 Bagor apabila katagori low dependence atau ketergantungan rendah.

Hasil pengumpulan data didapatkan dari pemeriksaan data oleh peneliti melalui pengamatan pada siklus I dan siklus II. Selanjutnya digunakan peneliti dalam mengambil sebuah kesimpulan bahwa konseling kelompok behavior tehnik kontrak perilaku dapat menurunkan ketergantungan merokok di kelas XI Perhotelan 2 SMK Negeri 2 Bagor Nganjuk

\section{HASIL PENELITIAN}

Peneliti selaku konselor menyusun perencanaan penelitian terhadap 5 sampel yang telah mengisi kuesioner ketergantunagn merokok. Adapun siswa tersebut di sajikan pada tabel 1.

Tabel 1. Data Siswa yang Memiliki Ketergantungan Merokok Sebelum Tindakan

\begin{tabular}{|c|c|c|c|}
\hline No & Nama & Skor & Ket \\
\hline 1 & $\mathrm{Ar}$ & 8 & \begin{tabular}{l}
\multicolumn{2}{c}{ Very } \\
high \\
dependence
\end{tabular} \\
\hline 2 & Ys & 9 & $\begin{array}{l}\text { Very } \\
\text { high } \\
\text { dependence }\end{array}$ \\
\hline 3 & $\mathrm{Di}$ & 9 & $\begin{array}{l}\text { Very } \\
\text { high } \\
\text { dependence }\end{array}$ \\
\hline 4 & $\mathrm{Gl}$ & 8 & $\begin{array}{l}\text { Very } \\
\text { high } \\
\text { dependence }\end{array}$ \\
\hline 5 & $\mathrm{Pj}$ & 9 & $\begin{array}{l}\text { Very } \\
\text { high } \\
\text { dependence }\end{array}$ \\
\hline \multicolumn{2}{|c|}{ Mean } & 8,6 & $\begin{array}{l}\text { Very } \\
\text { high } \\
\text { dependence }\end{array}$ \\
\hline
\end{tabular}

Dari skala ketergantungan diatas diperoleh 5 siswa memiliki ketergantungan merokok yang sangat tinggi dan didapatkan rata-rata hasil 8,60 dengan kategori ketergantungan sangat tinggi maka dari itu peneliti berusaha menurunkan ketergantungan merokok dengan konseling kelompok behavior teknik kontrak perilaku.

Setelah di lakukan konseling kontrak perilaku di peroleh skor kejenuhan belajar sebagai berikut:

Tabel 2. Data Ketergantungan Merokok siklus 1 setelah dilakukan konseling

\begin{tabular}{|c|c|c|c|}
\hline No & Nama & Skor & Ket \\
\hline 1 & $\mathrm{Ar}$ & 8 & Very high dependence \\
\hline 2 & Ys & 8 & Very high dependence \\
\hline 3 & $\mathrm{Di}$ & 7 & High dependence \\
\hline 4 & $\mathrm{Gl}$ & 7 & High dependence \\
\hline 5 & $\mathrm{Pj}$ & 6 & High dependence \\
\hline \multicolumn{2}{|c|}{ Mean } & 7,20 & High dependence \\
\hline
\end{tabular}

Dari hasil yang diperoleh setelah dilakukan konseling kelompok behavior dengan teknik kontrak perilaku menunjukkan kategori high dependence. Konselor dalam memberikan layanan konseling kelompok kurang maksimal dikarenakan konselor hanya fokus terhadap satu konseli yang menjadi prioritas utama. Selain kesepakatan anggota kelompok karena konseli tersebut sudah menunjukkan dampak yang ditimbulkan dari ketergantungan merokok. Ditandai dengan gejala batuk dan dari saran dokter siswa tersebut untuk segera menghilangkan atau menurunkan kebiasaan merokok. Hal itulah yang menyebabkan tidak semua anggota kelompok mendapatkan perlakuan yang sama dari konselor. Konselor dalam memberikan LKPD hanya di berikan pada satu konseli yang menjadi prioritas saja. Sehingga hasil yang didapatkan semua anggota kelompok .setelah mengikuti konseling kelompok tidak maksimal.

Berdasarkan hasil pengamatan siklus I belum menunjukan perkembangan yang signifikan ditunjukkan dengan hasil katogori sangat bergantung tinggi dengan nilai 7,2, dimana masih jauh dari kriteria keberhasilan. Maka konselor mengadakan perencanaan perbaikan guna memperbaiki kegiatan bimbingan konseling layanan konseling kelompok teknik kontrak perilaku untuk menurunkan ketergantungan merokok pada pelaksanaan siklus selanjutnya. 
Bimbingan dan Konseling Universitas PGRI Adi Buana Surabaya

ISSN: 02162938

Tabel 3. Data ketergantungan merokok siklus 1,2 dan siklus 3

\begin{tabular}{|c|c|c|c|c|c|c|c|}
\hline \multirow[t]{2}{*}{ No } & \multirow[t]{2}{*}{ Nama } & \multicolumn{2}{|c|}{ Siklus I } & \multicolumn{2}{|c|}{ Siklus II } & \multicolumn{2}{|c|}{ Siklus III } \\
\hline & & Skor & Ket & Skor & Ket & Skor & Ket \\
\hline 1 & Ar & 8 & $\begin{array}{l}\text { Very high } \\
\text { dependence }\end{array}$ & 5 & $\begin{array}{l}\text { Moderate } \\
\text { dependence }\end{array}$ & 3 & $\begin{array}{l}\text { Low } \\
\text { dependen }\end{array}$ \\
\hline 2 & Ys & 8 & $\begin{array}{l}\text { Very high } \\
\text { dependence }\end{array}$ & 5 & $\begin{array}{l}\text { Moderate } \\
\text { dependence }\end{array}$ & 3 & $\begin{array}{l}\text { Low } \\
\text { dependen } \\
\end{array}$ \\
\hline 3 & Di & 7 & $\begin{array}{c}\text { High } \\
\text { dependence }\end{array}$ & 6 & $\begin{array}{c}\text { High } \\
\text { dependence }\end{array}$ & 4 & $\begin{array}{l}\text { Low } \\
\text { depende }\end{array}$ \\
\hline 4 & $\mathrm{Gl}$ & 7 & $\begin{array}{c}\text { High } \\
\text { dependence }\end{array}$ & 5 & $\begin{array}{l}\text { Moderate } \\
\text { dependence }\end{array}$ & 3 & $\begin{array}{l}\text { Low } \\
\text { dependen }\end{array}$ \\
\hline 5 & Pj & 6 & $\begin{array}{c}\text { High } \\
\text { dependence }\end{array}$ & 4 & $\begin{array}{c}\text { Low } \\
\text { dependence }\end{array}$ & 2 & $\begin{array}{l}\text { Very Low } \\
\text { dependen }\end{array}$ \\
\hline Jum & llah & 36 & & 25 & & 15 & \\
\hline & a-rata & 7,2 & $\begin{array}{c}\text { High } \\
\text { dependence }\end{array}$ & 5 & $\begin{array}{l}\text { Moderate } \\
\text { dependence }\end{array}$ & 3 & $\begin{array}{l}\text { Low } \\
\text { depend }\end{array}$ \\
\hline
\end{tabular}

Berdasarkan table di atas terdapat penurunan ketergantungan merokok dari siklus 1,2 ke siklus 3 di mana rata-rata untuk siklus I adalah 7,2 siklus ke II adalah 5, dan siklus 3 adalah 3 maka terdapat penurunan ketergantungan merokok. Untuk lebih jelasnya bisa melihat grafik di bawah ini:

\section{GRAFIK KETERGANTUNGAN MEROKOK}

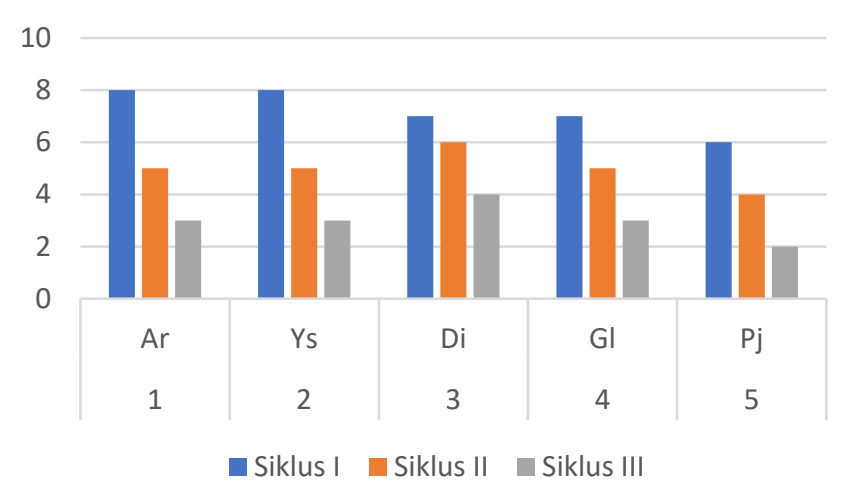

Adapun rata-rata dari ketergantungan merokok dapat di lihat grafik rata-rata dibawah ini, di mana terdapat penurun siklus I dan siklus II sebesar 2,2 sedangan siklus II dan III sebesar 2,0 untuk ketergantungan merokok.

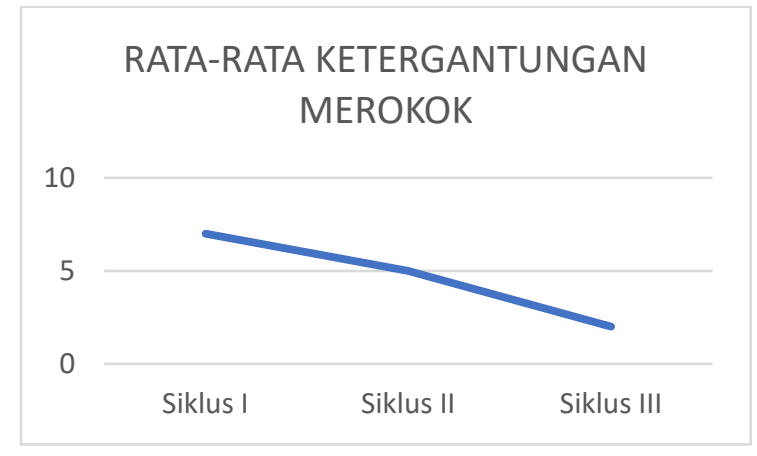

Dari hasil analisis pedoman pengamatan dan hasil post-test setelah konseling kelompok siklus 3 dapat diketahui bahwa semua konseli sudah optimal mengikuti kegiatan konseling kelompok, dan berdasarkan grafik rata-rata ketergantungan merokok sudah terjadi penurunan dari sangat tergantung ke cukup tergantung dan ketergantungan rendah. Sehingga dapat disimpulkan dalam konseling kelompok pendekatan behavior teknik kontrak perilaku dapat menurunkan ketergantungan merokok.

\section{KESIMPULAN DAN SARAN}

Dari hasil pemaparan dan penjelasan penelitian bimbingan dan konseling di atas maka penulis dapat menyimpulkan bahwa konseling kelompok behavior tehnik kontrak perilaku dapat berpengaruh dalam menurunkan ketergantungan merokok di kelas XI Perhotelan 2 SMK Negeri 2 Bagor Nganjuk

Tentunya hasil dari penelitian ini masih sangat jauh dari kata sempurna maka dari itu saran untuk semua pihak adalah terus belajar dengan membaca litelatur, mengembangkan dan mencari informasi dalam melakukan dan menggunakan teknik serta teori konseling dalam membantu menyelesaikan masalah konseli.

\section{DAFTAR RUJUKAN}

Ardini, R. F. \& Hendriani, W., 2012. Proses Berhenti Merokok Secara Mandiri Pada Mantan Pecandu Rokok Dalam Usia Dewasa Awal. Jurnal Psikologi Pendidikan dan Perkembangan No. 02 Juni 2012, Volume 1.

Ardita, Hafidz. 2015. Faktor-Faktor Yang Mempengaruhi Motivasi Berhenti Merokok Pada Mahasiswa Teknik Mesin UMY Angkatan 2015. Skripsi strata satu. Universitas Muhammadiyah Yogyakarta, Yogyakarta

Arikunto, S., 2013. Prosedur Penelitian: Suatu Pendekatan Praktik. Jakarta: Rineka Cipta.

Arniati, Layli Nur. 2014. Hubungan Antara Tingkat Stres Dengan Perilaku Merokok Perawat Pria Di RSUD Sukoharjo. Skripsi 
Bimbingan dan Konseling Universitas PGRI Adi Buana Surabaya

ISSN: 02162938

strata satu. Universitas Muhammadiyah Surakarta. Surakarta. Diakses 24 April 2017 pada http://eprints.ums.ac.id/28332/

Ayu, Zeri Winda. 2014. Tingkat Ketergantungan Merokok dan Motivasi Berhenti Merokok pada Pegawai Fakultas kedokteran gigi USU dan Supir Angkot di Medan. Skripsi strata satu. Universitas Sumatera Utara. Medan. Diakses 24 April 2017 pada http://repository.usu.ac.id/handle/123456789/ $\underline{41086}$

Depkes, 2013. Infodatin Hari Tanpa Tembakau Sedunia. [Online] Available at: http://depkes.go.id (Diakses 25 Oktober 2017).

Firzawati. 2015. Faktor Upaya Berhenti Merokok Pada Perokok Aktif Umur 15 Tahun Keatas Di Indonesia. Disertasi. Universitas Indonesia. Jakarta. Diakses 01 Mei 2017 pada https://www.lib.ui.ac.id/file?file=digital/2016 - 4/20416068-D2086-Firzawati.pdf

Sugiyono, 2016. Metode Penelitian Kuantitatif, Kuaitatif, dan R\&D. Bandung: Alfabeta.

Tcandra, 2012. Kementrian Kesehatan Republik Indonesia. [Online] Available at: $\quad$ http://www.depkes.go.id/

(Diakses 30 November 2017). 